歯の退化香 す 2 例 歯の退化を示す 2 例 九州雬科大学口腔組織学教室（指導：三枝 博教授）

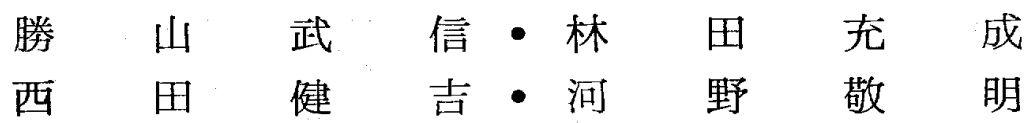

\section{緒 \\ 人の雷は、その時代の環境的変化に応じ、僅かづつ} ではあるが進化のコースを辿つている。従つて現代人 の柬の形態は種々な退化現象を示し、時にはかなり進 んだ退化形態を諗めるととがある。しかららば退化現象 とは、どういつた形態的変化をいうのであろうか。 即ち形の縮少及び単純化、更に目雨部では陵頭数の減 少或いは雪根の融合等である。忠た看群全体として考 えるならば永久雪に於ては大体切歯、小曰蒾、大曰柬 各群の遠心のもの程その傾句か強く、極端な場合、歯 は久徐し曾数の減少を来たすととさえある。又各個々 の菌でも遠心部より退化傾向が現われるが、とれに就 て汒 Bolk の Terminale reduktion 説、藤田氏 その他数多くの文献で既に知られている通りである。 特に下顎切菌及び小曰歯群（山田）で注通常近心のも のから退化するという。

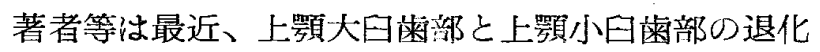
と思われる例に遭遇したのでしてに報告する。

\section{調 查 方 法}

先づ被検者の口腔内検者及び問㟝を行つた後、全顎 石高模型を調整し、てれいよつて調査計測したが更に レントゲス写真を参考に供した。尚計測にあつては退

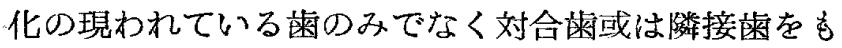
計測した。勿論計測值の比較には石高模型によつて行 なわれたものを用いた。

\section{調 查 所 見}

例 I 小O英○ 24才 우

$$
\begin{aligned}
& \begin{array}{l}
\times(7)(6) 54321 \\
\hline \times 7654321
\end{array} \\
& 76 \cdots \mathrm{C}_{2} \times \text { ㅍ…....万人徐 } \\
& \text { O印......症例㸃 }
\end{aligned}
$$

智歯を徐く全歯28本が現存、上顎第 1 及び第 2 大曰 米以外は略んど正常形熊を保持し、日歯部の計測值。
表 1、2、5 亿示す如く上顎大日雪以外は大差がな い。上顎第 1 大田歯の近遠心径も左程差はないが、煩 舌径はやや小さい。従つて雬冠長幅指数は小さく 100 に近くなつている。第 2 大曰雪は近遠心径も煩舌径す 小さいが、第1大日歯と反対に近遠心径の縮小率は指 数值によつても明汃示されている如く大である。乙 れは上顎第 2 大曰歯の退化傾向加近遠心的な恃平とし て現われたものであろう。

次に雨冠の形を㫕るに、第 1 大曰梳左右側とも遠心 舌側㖫頭が退化消失し 3 咬頭をなしているため、咬合 面の外形记三角形様で第 1 大曰四の基本形態である菱 形と異なり統計的にも珍らしい形である。第 2 大曰函 の左側のもの心前者同様遠心舌側咬頭は消失し 3 昗頭 を示しているが、遠心煩側咬頭も可成り退化し付加結 節の状態を現し、一見 2 咬頭様を呈している。また右 側の6のは左側と一様に見えるが、頓側は 3 コの小結 節状をなして、菊冠は全体的に蕾状曾の様相を示し全 く退化の著しい智雪の如き外観である。従つててれら の咬合面に於ける隆線も溝す不規則である。虫た智菌 は被検者によれば抜去の経験がなく、 $\mathrm{X}$ 線にも現われ ないため先天的欠徐と考えられる。

下顎大曰柬部では特に画側の智茵が久徐している以 外退化傾向は略んど見られず、第 2 大日荬は 4 咬頭で 溝礼十字型を示し、Hellman の分類による+4型で ある。また第 1 大日曾は 5 咬頭で湿は $\mathrm{Y}$ 字型を示し Gregory の Drgopi the cup Pattern である。

以上の如く本例は退化が上顎大曰歯群の遠心から即 ち第3、第 2 更に第 1 大曰に及んだものと推察する。

例II 本O一O 38才 今

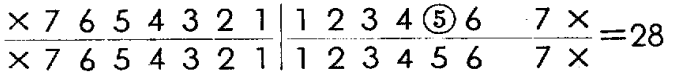

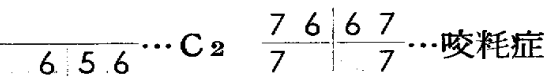




\section{- 240 - (102) 崡 $の$ 退化店示す 2 例}

表 1 Measurment of the mesio-distal diameter of the crown

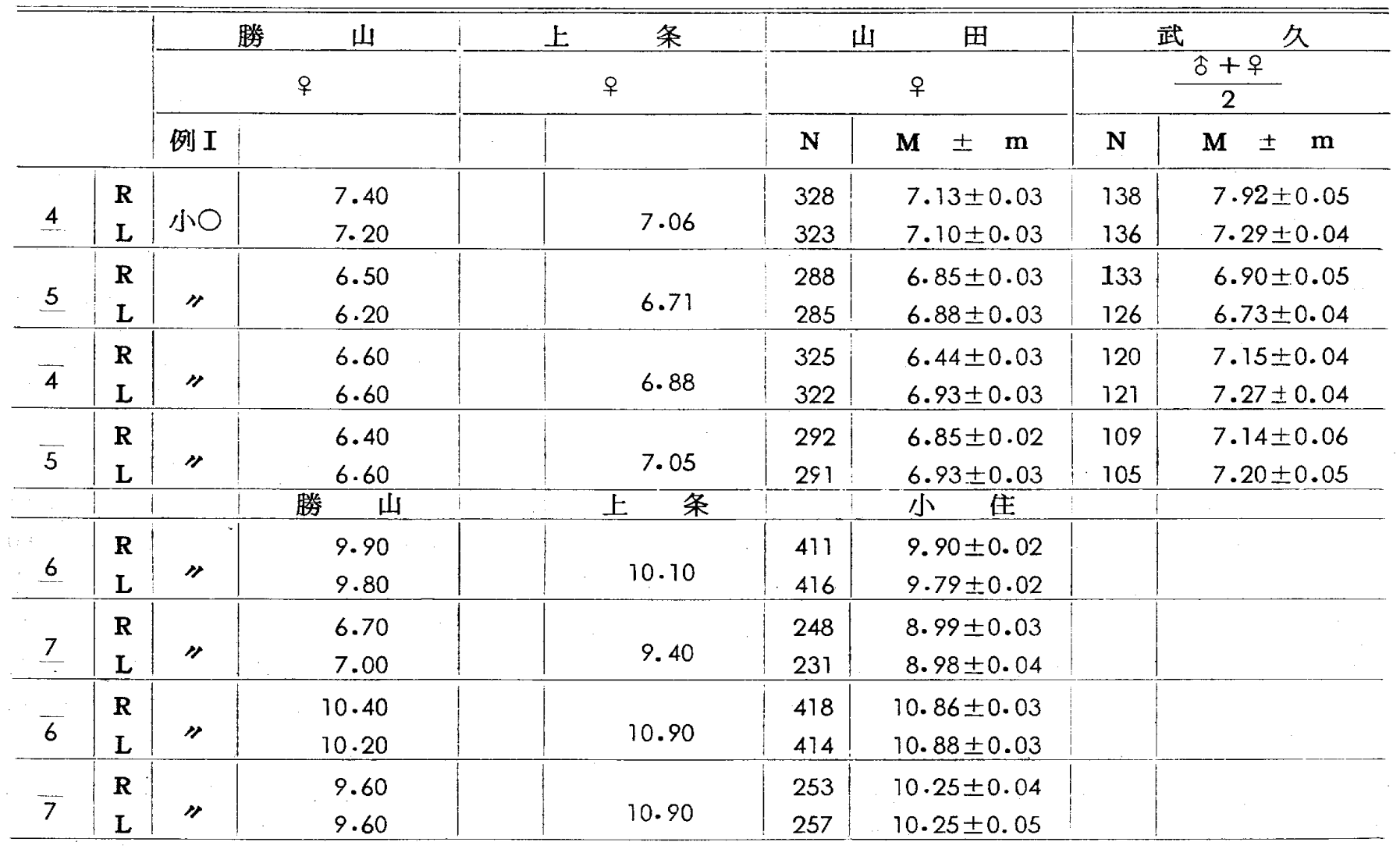

表 2 Measurment of the bucco-lingual diameter of the crown

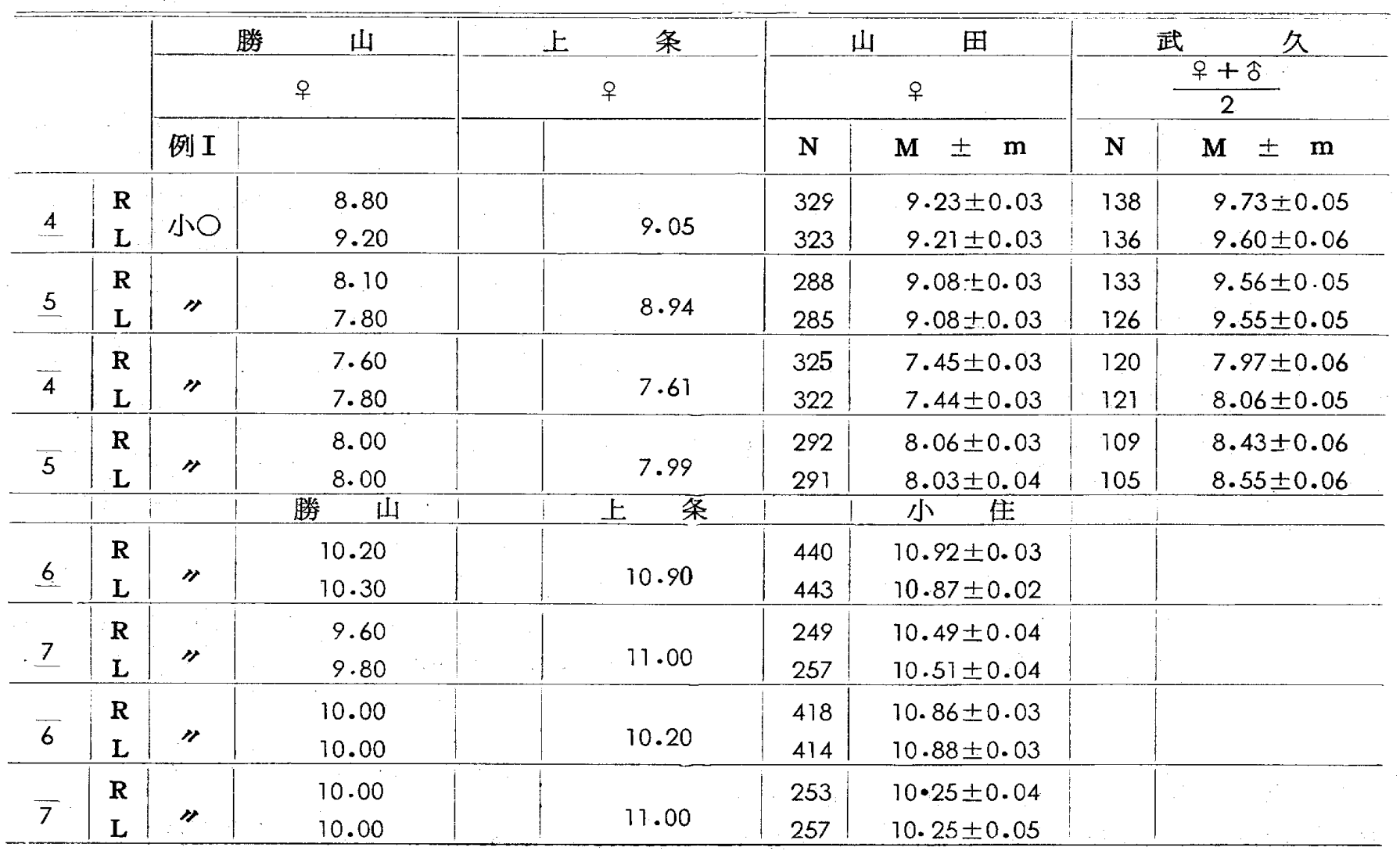


表 3 Measurment of the mesio-distal diameter of the crown

\begin{tabular}{|c|c|c|c|c|c|c|c|c|}
\hline & \multirow{2}{*}{\multicolumn{2}{|c|}{ 勝 }} & \multirow{2}{*}{ 上 } & \multicolumn{2}{|c|}{ 山 田 } & \multicolumn{2}{|c|}{ 武 久 } \\
\hline & & & & & & 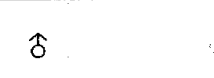 & \multicolumn{2}{|c|}{$\frac{\hat{o}+q}{2}$} \\
\hline & & 例 II & & & $\mathbf{N}$ & $\mathbf{M} \pm \mathbf{m}$ & $\mathbf{N}$ & $\mathbf{M} \pm \mathbf{m}$ \\
\hline \multirow{2}{*}{4} & $\mathbf{R}$ & & 8.00 & \multirow{2}{*}{$7 \cdot 30$} & 342 & $7.20 \pm 0.03$ & 138 & $7.92 \pm 0.05$ \\
\hline & $\mathbf{L}$ & 不O & 8.00 & & 341 & $7.16 \pm 0.03$ & 136 & $7.29 \pm 0.04$ \\
\hline \multirow{2}{*}{5} & $\mathbf{R}$ & \multirow[b]{2}{*}{ " } & 6.00 & \multirow[b]{2}{*}{6.86} & 318 & $6.91 \pm 0.03$ & 133 & $6.90 \pm 0.05$ \\
\hline & $\mathbf{L}$ & & 4.60 & & 323 & $6.79 \pm 0.03$ & 126 & $6.73 \pm 0.04$ \\
\hline \multirow[b]{2}{*}{4} & $\mathbf{R}$ & \multirow[b]{2}{*}{ " } & 690 & \multirow[b]{2}{*}{7.00} & 341 & $6.65 \pm 0.03$ & 120 & $7.15 \pm 0.04$ \\
\hline & $\mathbf{L}$ & & 6.90 & & 337 & $6.85 \pm 0.03$ & 121 & $7.27 \pm 0.04$ \\
\hline \multirow{3}{*}{5} & $\mathbf{R}$ & \multirow{3}{*}{$\mu$} & 7.00 & \multirow{2}{*}{7.17} & 316 & $7.04 \pm 0.03$ & 109 & $7.14 \pm 0.06$ \\
\hline & $\mathbf{L}$ & & 7.00 & & 319 & $7.01 \pm 0.03$ & 105 & $7.20 \pm 0.05$ \\
\hline & & & 勝 山 & 上 条 & & 小 住 & & \\
\hline \multirow[b]{2}{*}{6} & $\mathbf{R}$ & \multirow[b]{2}{*}{$\geqslant$} & 11.40 & \multirow[b]{2}{*}{10.60} & 448 & $10.16 \pm 0.02$ & & \\
\hline & L & & 11.40 & & 449 & $10.10 \pm 0.02$ & & \\
\hline \multirow[b]{2}{*}{7} & $\mathbf{R}$ & \multirow[b]{2}{*}{$"$} & 9.90 & \multirow[b]{2}{*}{10.00} & 279 & $9.82 \pm 0.03$ & & \\
\hline & $\mathbf{L}$ & & 9.90 & & 281 & $9.83 \pm 0.03$ & & \\
\hline \multirow[b]{2}{*}{6} & $\mathbf{R}$ & \multirow[b]{2}{*}{$"$} & 12.40 & \multirow[b]{2}{*}{11.60} & 452 & $11.21 \pm 0.03$ & & \\
\hline & $\mathbf{L}$ & & 12.40 & & 451 & $11.25 \pm 0.03$ & & \\
\hline \multirow[b]{2}{*}{7} & $\mathbf{R}$ & \multirow[b]{2}{*}{$"$} & 12.00 & \multirow{2}{*}{$13 \cdot 10$} & 286 & $10.72 \pm 0.04$ & & \\
\hline & $\mathbf{L}$ & & $12 \cdot 00$ & & 286 & & & \\
\hline
\end{tabular}

表 4 Measurment of the bucco-lingual diameter of the crown

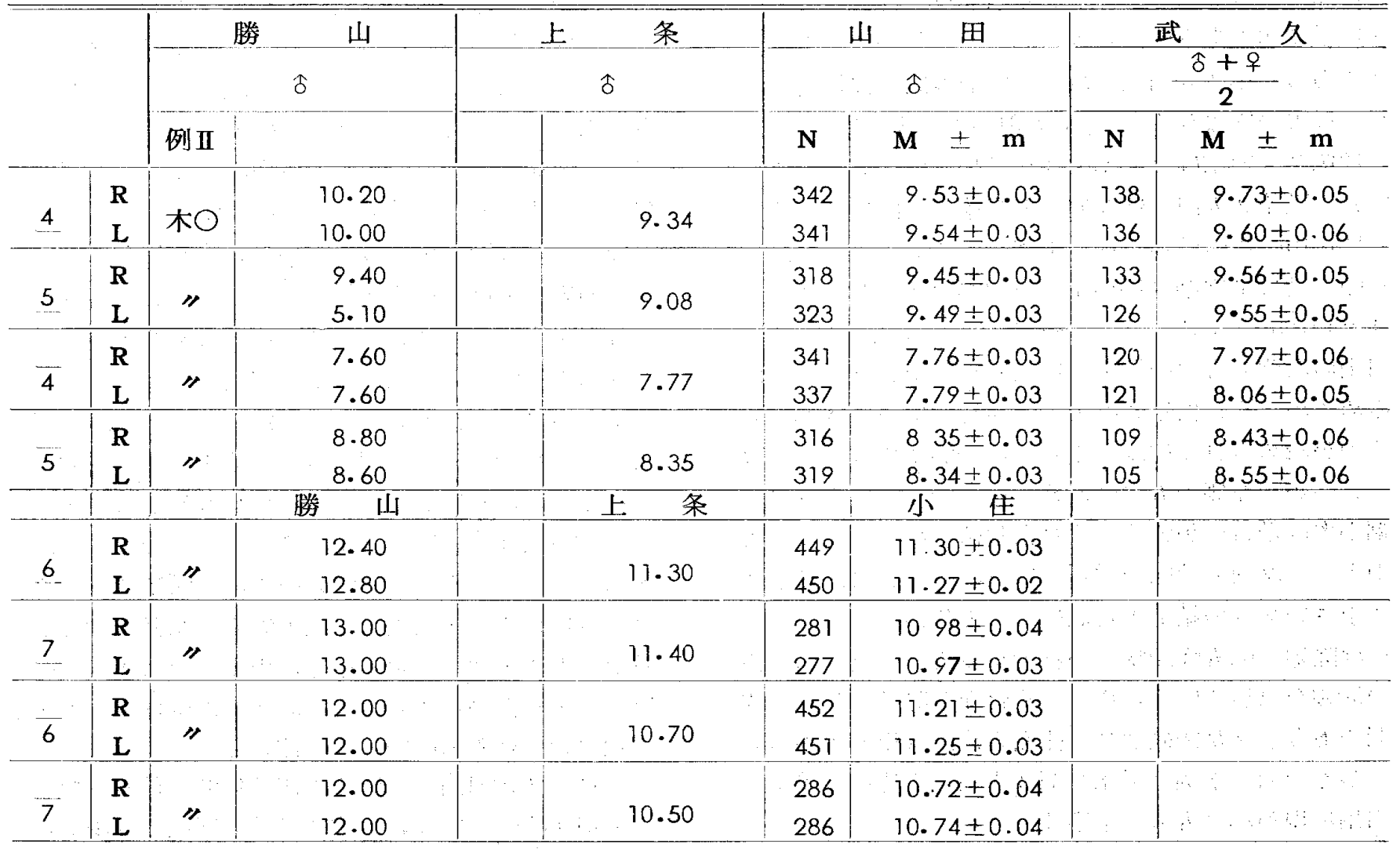




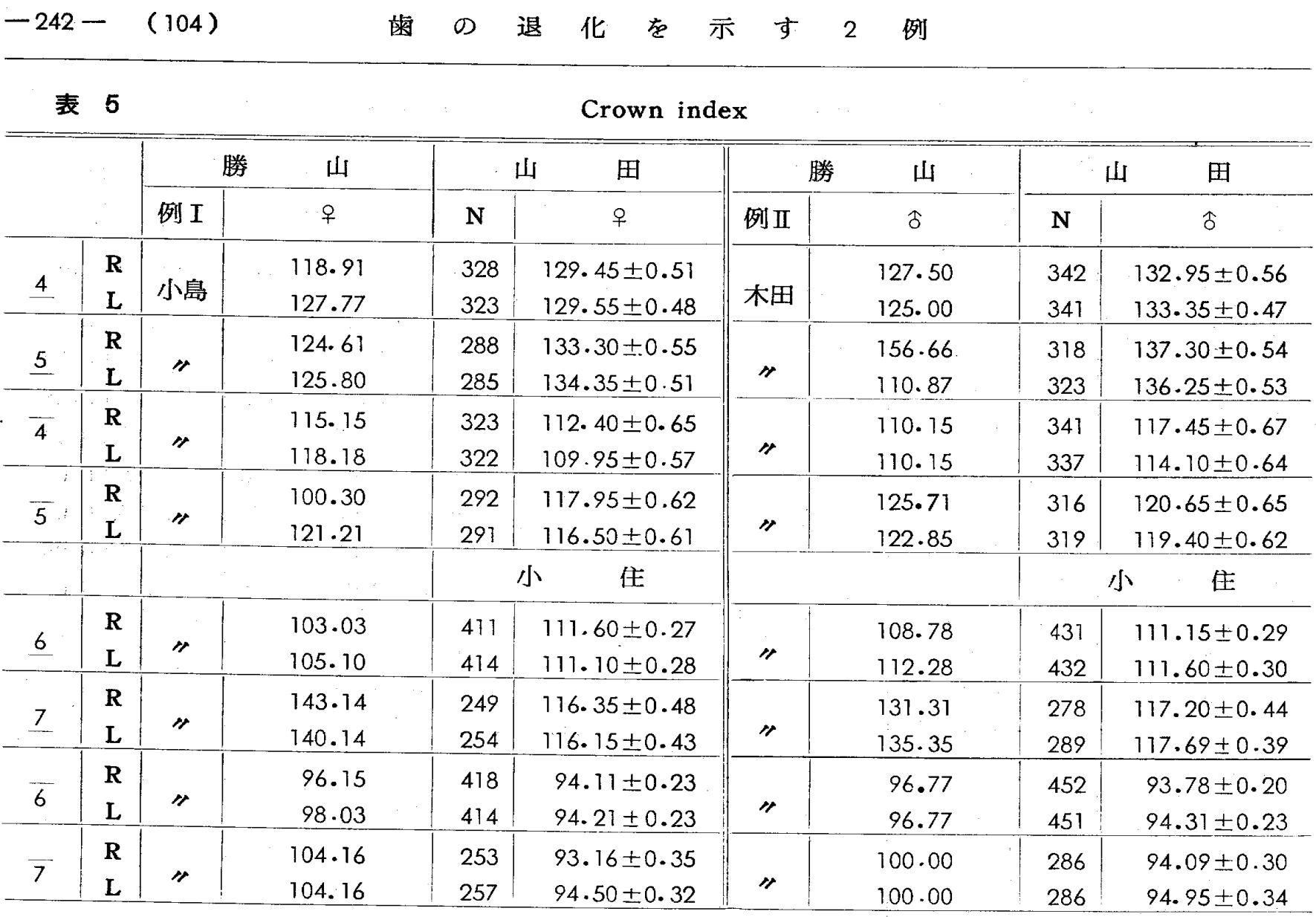

智蒾を除く全霜28本現存、上顎左側第 2 小曰宩以外 は略んど正状形態を示し、計測值に於ても表 3、4、 5 亿示す如く文献の值と大差はなく、むしろ大きいよ うである。第 3 大田菊（智雪）は前者同様被検者によ れば抜去の経験なく、X線にも現われず先天的に欠徐、 上顎第 2 大曰宷は 4- 或は $3+$ (咬粍のため明白でな い）下顎第 2 大曰歯は 5 型、上䫴第 1 大曰歯は 4 咬頭 (Dahlberg の分類では 4 +型) 下顎第 1 大曰電は 5 昗頭で湿はY 字型 (Hellman $の$ 分類で $\mathrm{Y}_{5}$ 型) にして Dryopithecus Pattern を示している。上顎第 2 小 日歯の右側のものの煩舌径は大差ないが、近遠心径は 極めて小さく、指数值は大で近遠心的に圧平されてい るのが虫められる程度で䨑冠の形態的変化は見られな い。しかし左側のものは近遠心径も煩舌径も小さいが 縮小率は頓舌径が強く、また指数值す小さく右側のも のと全く反対の傾向を示している。更に咬合面は煩側 に小さい2コの結節と舌側に 1 コの咬頭を有し、近心 辺縁隆線上にす隆起状の小結節が見られ、全く蕾状雨 の形態を呈している。従つて咬合面の隆線や撃は不規 則であり、また頝側及び舌側面の形態も単純である。

かくく如く本例は退化が第 3 大白歯と片側の第 2 小 日崡に現われたものと推察する。
総—括

人の雨は現在一定の法則にしたがつて退化している てとは前記した通りであるが、退化は極めて複雑で あつて人種間にも、また同一人種間にも差があり、一 本の䨑に於ても同時にしかも一様に出現するものでは ない。現在最も退化しつつある粜は集知の如く智雨に 次ぎ上顎側切歯、上顎第 2 小曰粟の順に、前記した如 く種々な形態的変化即ち形の縮小、咬頭数の減少（咬 頭の消失)、歯冠の近遠的及び頓舌的圧平或は雨根の融 合等が見られ、退化が最も進んだ場合霜は欠徐する。

今回の報告例は上顎大曰霜と智霜特に上顎小正歯部 に出現した退化例である。即ち例 1 は上䫇大白歯部の 全体にわたつて退化が認められ、第 1、2大票はと 乌に左右対称的に形が小さく、しか子咬頭数が減小し

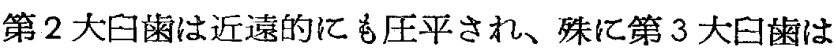
久徐している。そてで上顎大田雨の咬頭数について観 察するに、第 1 大日雪は小住鈴木、酒井 も99\%が 4 㖫頭であると述べ、更に小住は男より女に 4 咬頭の少 ないてとを指摘している。皮肉にす本例は女であるが 1 例なので性差の問題は差し控える。

また第 2 大田䅈について小住は63\%、鈴木、酒井は $58 \%$ が 4 㖫頭とい5。本例に於ける同雪の3咬頭は、 
第 1 大曰米に比較するとさほど珍らしいことはない が、しかし避心舌側咬頭の退化消失に次ぎ遠心煩側咬 頭が退化し、2 咬頭に近い形態をなしているてとは退 化が可成り進んだものと考えられる。次に下顎大臼曾 群を観察するに、第 1 大曰幽は 5 咬頭で溝は $\mathrm{Y}$ 字型、 第 2 大田歯は 4 咬頭で溝は十字型を示し、ある程度の 退化が後方雪より現われているが上顎ほど著明では ない。

例 2 は智雪及び上䇺第 2 小曰歯を徐く以外の歯は正 常形態を保持し退化像は見られない。本例の上顎左側 第 2 小曰函は形驡の縮小と霜冠形の単純が認められ、 咬合面は全般的に丸味を帯びた蕾状畨様を呈してい る。しかし右側の同名雨仙僅かに近遠心的な縮小が見 られる程度である。大霜は一般に大きく、上顎第 1 大曰雪法 4 咬頭、下顎のものは 5 咬頭、上顎第 2 大曰 柬は 4 -或㹥 $3+$ 十下顎のものは+5 示し、第 3 大 日霜は上下左右側とも欠徐している。以上の如く例 1 は上顎大白蒾群全体に、例 2 は智菌殊飞上顎左側第 2 小曰雨に退化の現われた珍らしい例である。

\section{結 論}

例 1 は24才の女で上顎第 1 大曰歯结左右側とも形が 小さく遠心舌側咬頭は退化消失し 3 咬頭、第 2 大曰菌 は左右側とも更に小さく近遠心的に压平され、3咬頭

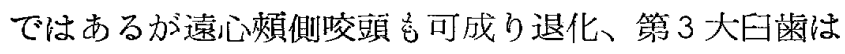
上下左右側とも先天的欠徐し、上顎大曰菌群全般に退 化の現われた例である。

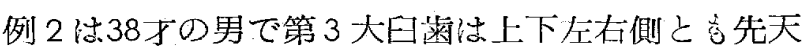
的に欠徐、上顎左側第 2 小曰荬は極めて倭小にして、 歯冠は雪状曾の様相を示し、智雪殊に上顎左側第 2 小 日雪に退化の現われた例である。

\section{主な参考交献}

1) Fred J. Ludwig; The mandibular second premolars morphologic variation and in heritance. J. of Dental Research, 36. 1957

2) Sshour land $M$ assher $M$; The development of the human dentitior, J. of the American Dental Association. 28, 1941

3）藤田恒太郎；雪の解剖学、金原書店、昭和34年 (1959)

4）柴田 信; 霜车形態学、4 版、金原書占、炤和 12年 (1937)

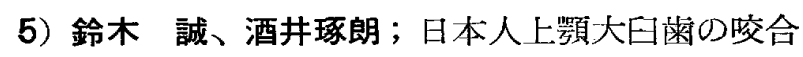

面形態一特に遠心舌㑡咬頭の退化に就て、人類学 雑誌、第 05 巻、第 2 号、昭和31年 (1956)

6）鈴木 諴、酒井㻟朗；日本人下顎小曰歯の歯冠 形態、日本人類学会日本民族学協会連合大会第 12 回記事、昭和32年 (1957)

7) 武久 滋; 米白人歯牙と日本人歯牙の人類学的 ならびに形態学的比較研究、東京画科大学解剖学 教室業績集、4 輯、昭和32年 (1957)

8）鹿井克己；日霜咬合面に於ける裂溝の形態につ いて、熊本医学会雑誌、31巻補冊 3、昭和32年、 (1957)

9）中村敞雄; 日本人の下顎大巨雪々冠の形態に関 する研究、解剖学染誌第32巻、第 5 号、昭和 32 年 (1957)

10）鈴木 誠、酒井玩朗；日本人上顎大曰電の咬合 面形態一特に遠心煩側咬頭の退化について、人類 学雑誌第67巻第 4 号、昭和34年 (1959)

11）山田 博; 人類小曰歯菡冠の形態学的研究、九 州菌科学会雑誌、第 17 巻 第 $3 、 4$ 号、昭和 39 年 (1964)

12）小住啓一; 日本人大曰歯並びに第二乳曰歯歯冠 の形態学的研究、九州歯科学会雑誌第 14 巻第 3 号 (臨時号) 昭和35年 (1960)

13）上条雍彦; 日本人永久歯の解剖学、東京歯科大 学解剖学教室、昭和37年 (1662)

14）住谷 靖; 日本人に扣ける雷の異常の統計的観 察、人類学雑誌第67巻第 4 号、昭和 34 年 (1959)

15）野田 穣、中村正義、大野静夫; 第二小囦歯の 一退化現象と看做すべき形態異常と欠如の一例、 日本之函界246号、昭和15年(1936)

16）阿保喜七郎；稀有なる上顎第一小罒矮小获の一 例、歯科学報、47号、昭和17年 (1941)

17）相良好仁；上顎第 2 小曰雨に発現した円錐歯の 一例、臨床歯科198号、昭和27年 (1952)

\section{写 真 説 明}

1. 例 10 上顎石高模型

2. 同上の左側白霜部

3. 同上の右側曰粤部

4. 例 20 上顎石高模型

5. 同上の一部拡大

6. 同上のX線写真 

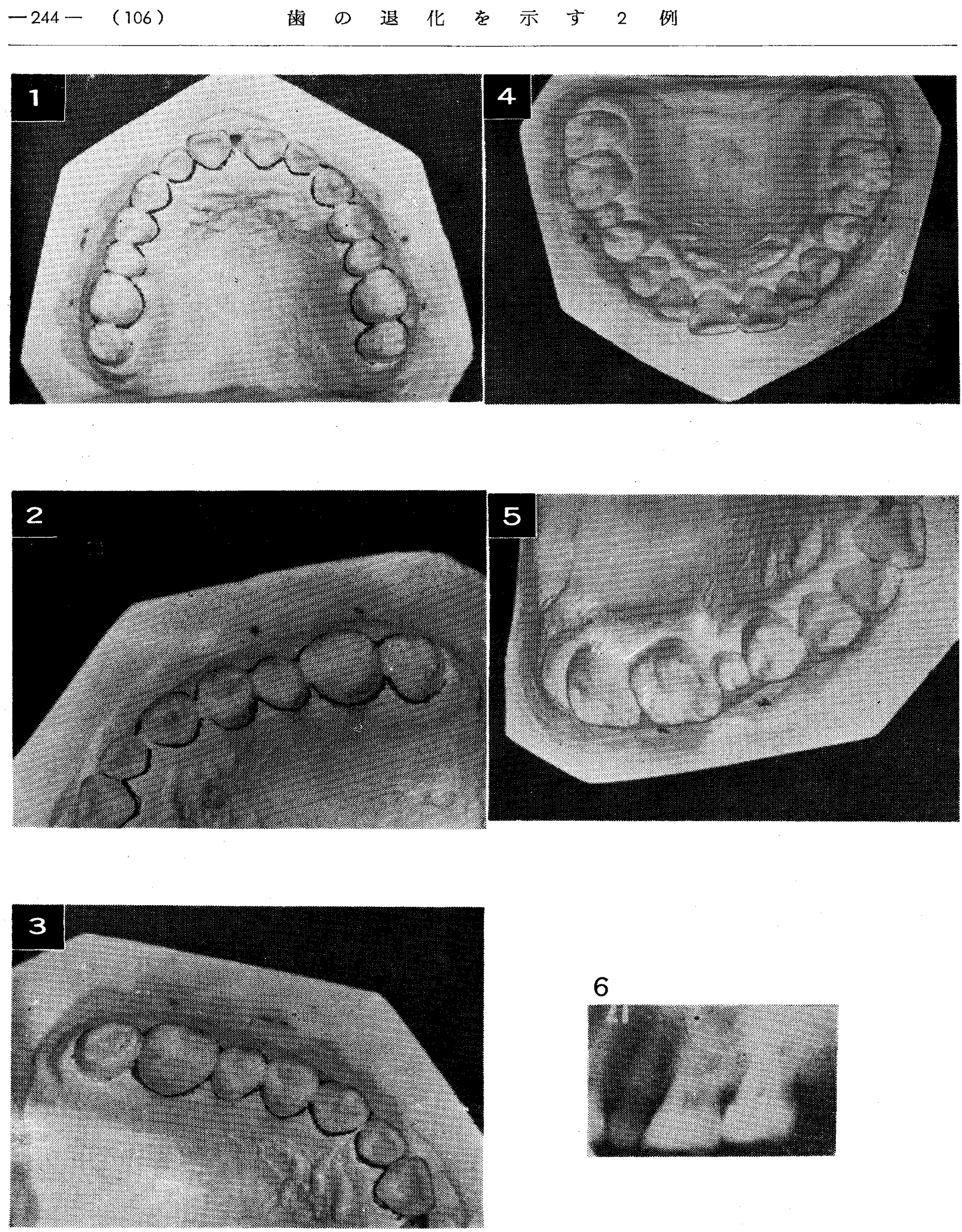


\title{
TWO CASES OF MARKED DEGENERATION IN THE MOLAR TEETH AND PREMOLAR TEETH OF THE UPPER JAW
}

\author{
by \\ Takenotu Katsuyama, Mitsunari Hayashida, \\ Kenkichi Nishida, Takaaki Kawano \\ Department of Oral-histology. Kyushu Dental College
}

\begin{abstract}
Marked variations of tooth forms were encountered in two subject's mouths which strongly suggested some degenerative changes.

The first case was a female aged 24 who had the upper 1st molars in both sides of jaw with a diminutive size, and these teeth appeared to have 3 cusps, because of the lack of the disto-lingual cusp, apparently by degeneration. The 2 nd molars of both dental arches were more pronouncedly reduced in sice than the 1st molars, and appeared flattened mesio-distally. These teeth were also three-cusped by the lack of disto-lingual cusp, and, in addition, their disto-buccal cusps showed a sign of degeneration. In this subject, the 3 rd molars of both dental arches were congenitally missing and all the other upper molar teeth showed more or less general picture of degeneration. However, the remaining dentition appeared normal in the development.
\end{abstract}

The 2 nd case was a male of 38 years of age in whom the upper left 2 nd molar was extremely diminutive like a dwarf tooth, and its crown assumed a buci-like form.

The same tooth on the opposite dental arch was normally contoured except that its mesio-distal width was slightly reduced. His 1 st premolar and the remaining members of whole dentition showed no sign of degeneration, and appeared rather slightly larger sized than the normal. 